\begin{tabular}{l} 
Missio Ecclesiae \\
ISSN 2086-5368 (Print) \\
ISSN 2086-5368 (Online) \\
https://jurnal.i3batu.ac.id/index.php/me \\
Vol.10, No.2, pp. 126-137, 2021 \\
\hline
\end{tabular}

\title{
Faktor-faktor Penyebab Pendeta Perempuan Menjadi Korban KDRT di Kota Kupang Provinsi Nusa Tenggara Timur: Dari Perpespektif Gereja Masehi Injili di Timor
}

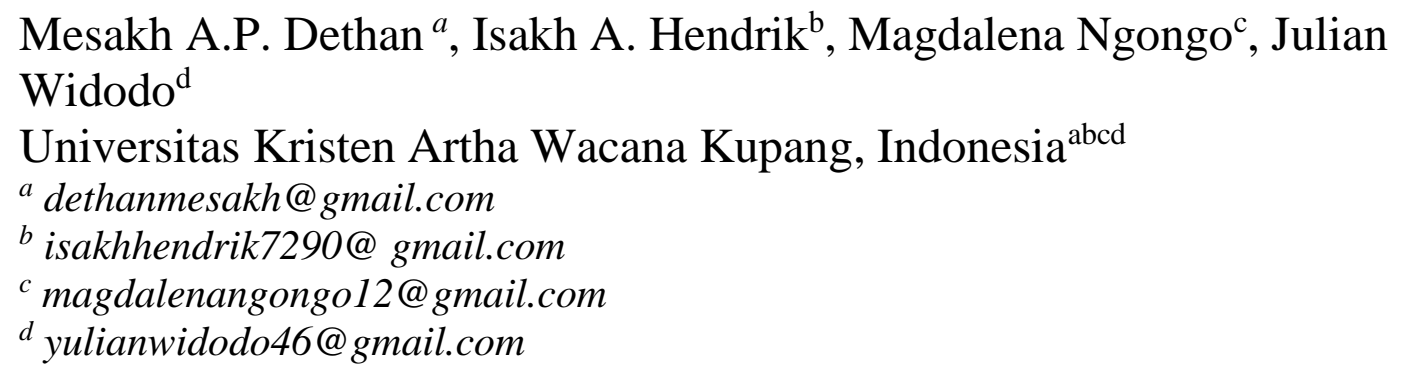

\section{INFO ARTIKEL}

Sejarah Artikel:

Diterima: September

2021

Direvisi: Oktober 2021

Disetujui: Oktober

2021

Dipublikasi: Oktober 2021

Kata Kunci:

Faktor-faktor penyebab, pendeta perempuan, korban KDRT.

Keywords:

Causal factors, female pastors, victims of domestic violence

\begin{abstract}
ABSTRAK
Riset ini bertujuan mengenali faktor-faktor pemicu pendeta perempuan jadi korban KDRT serta sejauhmana tindakan Gereja Masehi Injili di Timor terhadap kekerasan dalam Rumah Tangga (KDRT) yang dirasakan oleh para pendeta perempuan, yang bisa dijadikan selaku kajian serta bahan pendidikan dalam menghindari serta menanggulangi KDRT.

Riset ini memakai metode penelitian kualitatif. Pendekatan riset kualitatif yang diseleksi sebab menekankan pada fenomena/kenyataan, arti penalaran, suasana tertentu (dalam konteks tertentu), ataupun lebih banyak mempelajari hal-hal yang berhubungan dengan kehidupan setiap hari.

Hasil riset menunjukkan bahwa faktor-faktor pemicu KDRT tidak hanya aspek kecemburuan dari suami, tekanan ekonomi, atau sebab karena suami yang ratarata pemabuk dan suka berjudi, suami dengan tingkat pendidikan yang kurang dari isrtinya, suami yang hiperseks, suami dengan gangguan psikologis, namun juga jadwal istri yang padat dengan pelayanannya sehingga suaminya merasa ditelantarkan. Di lain pihak upaya GMIT melalui UPP Pastoral kepada mereka masih sebatas pemberian saran-saran tanpak melaksanakan pendalaman terhadap perkara yang mereka rasakan. Hasil riset penelitian menampilkan kalau GMIT belum mempunyai SOP yang memungkinan proses pemulihan untuk korban KDRT yang dilakukan secara terprogram dan sistimatis. Para korban malah bertambah stress sebab selain ketiadaan pemasukan akibat ditarik dari pelayananya selaku pendeta, dan lagi mendapatkan stigma negatif dari rekanrekan pendeta serta.
\end{abstract}

\section{ABSTRACT}

This research aims to identify the factors that trigger female pastors to become victims of domestic violence and the extent to which the Evangelical Christian Church in Timor acts against domestic violence (KDRT) experienced by female 
pastors, which can be used as studies and educational materials in avoiding and overcoming domestic violence.

This research uses qualitative research methods. The qualitative research approach was selected because it emphasizes the phenomenon/reality, the meaning of reasoning, a certain atmosphere (in a certain context), or learning more about things related to everyday life.

The results of the research show that the triggering factors for domestic violence are not only jealousy from the husband, economic pressure, or because the husband is on average drunk and likes to gamble, husbands with less education than their wives, husbands who are hypersexual, husbands with psychological disorders, but also the wife's busy schedule with her ministry so that her husband feels neglected. On the other hand, GMIT's efforts through Pastoral UPP to them are still limited to providing suggestions without carrying out a deepening of the cases they feel. The results of the research show that GMIT does not yet have an SOP that allows the recovery process for victims of domestic violence to be carried out programmatically and systematically. The victims were even more stressed because apart from the lack of income due to being withdrawn from their ministry as pastors, they also received negative stigma from fellow pastors as well.

\section{PENDAHULUAN}

Pendeta adalah "public figure" yang penting dalam masyarakat. Jabatan pendeta adalah jabatan yang mulia dan terhormat dalam jemaat. Mereka juga menjadi panutan warga jemaat. Pendeta yang hidup berumah tangga dan membangun keluarganya adalah sesuatu yang wajar. Berlainan adalah tradisi katholik dimana para pastornya tidak menikah dan membentuk keluarganya.

Pendeta yang menikah serta mempunyai keluarga nyatanya tidak bebas dari persoalan-persoalan rumah tangga. Banyak kelurga pendeta perempuan yang menghadapi relasi yang tidak nyamans karena salah satu pasangannya melakukan Kekerasan Dalam Rumah Tangga (KDRT) dalam bermacam-macam wujud, mulai dari cacian dan kata-kata kasar sampai dengan kekerasan fisik lainnya. Sekalipun sebuah perkawinan telah mendapat legalaitas penguasa serta agama dan badan adat tetapi tidak menutup kemungkinan adanya kekerasan yang merugikan pendeta perempuan dalam berbagai-bagai bentuk dan aspek.

Tujuan membuat rumah tangga menjadi masalah ketika terjadi kesenjangan ikatan pria dan wanita. Tentu hal ini berlawanan dengan ajaran kekristenan yang melihat Rumah Tangga selaku bagian dari keluarga Allah (Familia Dei) yang seharusnya mencerminkan ketentraman dan kedamaian. Dan bahkan mestinya menjadi panutan dalam masyarakat.

Dalam ajaran kristen Rumah Tangga dilihat selaku miniatur keluarga Allah seharusnya mendapatkan perlindungan. Perlindungan itu juga diatur dalam Undang-Undang No.23 Tahun 2004 mengenai Penghapusan KDRT memahami kekerasan dalam rumah tangga sebagai sebuah perbuatan terhadap seseorang, terutama perempuan yang berakibat timbulnya kesengsaraan atau penderitaan secara fisik, seksual, psikologis, dan atau penelentaraan rumah tangga termasuk ancaman untuk melakukan perbuatan, pemaksaan, atau perampasan kemerdekaan secara melawan hukum dalam lingkup rumah tangga.

Berikutnya Undang-undang Penghapusan KDRT juga menerangkan, 4 wujud kekerasan yang kerap terjadi dalam rumah tangga yakni: pertama, Kekerasan fisik sebagai perbuatan yang mengakibatkan rasa sakit, jatuh sakit, atau luka berat; kedua, Kekerasan kejiwaan, adalah perbuatan yang mengakibatkan lenyapnya rasa percaya diri, lenyapnya 
kemampuan untuk bertindak, rasa tidak berdaya, dan atau penderitaan psikis berat; ketiga, Kekerasan seksual, adalah pemaksaan ikatan seks baik kepada anggota keluarga dalam rumah atau sekitar, termasuk dengan maksud komersial atau maksud lainnya; dan keempat, Penelantaraan, adalah tindakan mengabaikan orang yang sebenarnyasesunguhnya menurut hukum menjadi tanggungjawabnya atau membatasi seseorang sehingga bergantung dan merasa dikendalikan.

\section{KAJIAN LITERATUR}

Kenyataan sudah membuktikan bahwa tidak sediit RT dan keluarga Kristen yang sudah menghadapai kekerasan dalam bermacam-macam wujud terutama yang dialami oleh anak-anak, Remaja dan para perempuan. Bersumber pada keadaan diatas, maka yang menjadi perumusan masalah disini adalah apakah faktor-faktor penyebab para pendeta perempuan mengalami Kekerasan di dalam Rumah Tangga (KDRT).

Selaku potret awal perlu diinformasikan disini data KDRT semenjak tahun 2015 hingga dengan tahun 2019 lalu.

\section{Kekerasan Dalam Rumah Tangga}

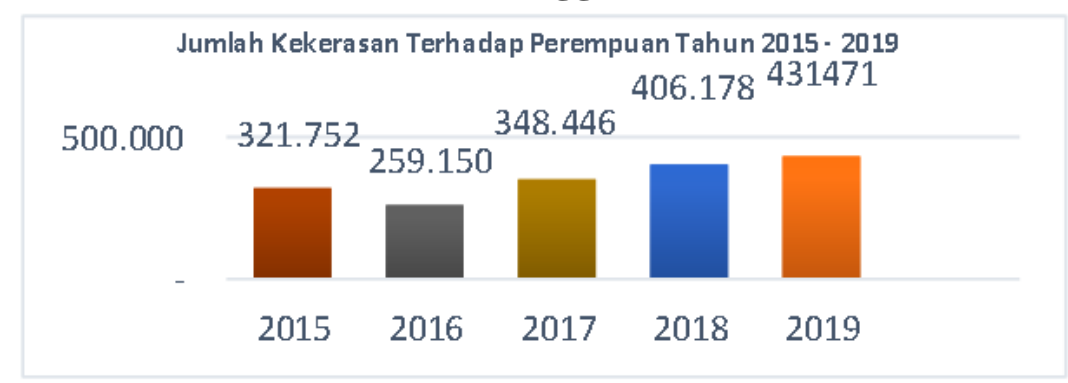

Tabel 1. Komnas Perempuan, Catatan Tahunan Tentang Kekerasan Terhadap Perempuan Tahun 2019(Komnas Perempuan, n.d.-a)

Dari tabel di atas menunjukkan ada peningkatan yang signifikan dari kekerasan terhadap kaum perempuan sesuai dengan data dari Komnas Perempuan (Komnas Perempuan, n.d.-b). Dari tahun ke tahun kita melihat adanya peningkatan sebesar $6 \%$ dari kasus-kasus kekerasan terhadap perempuan sampai dengan tahun 2019. Bahkan dari data yang kami peroleh dari tahun 2020 nampak juga trend peningkatan jumlah kekerasan itu semakin meningkat yakni dari 431.471 kasus kepada jumlah sebesar 406.178".

Jumlah kekerasan terhadap perempuan yang semakin meningkat itu dapat dirincikan lagi ke dalam berbagai bentuk kekerasan seperti kekerasan fisik $43 \%$, kekerasan seksual 
$25 \%$, kekerasan psikis $19 \%$ dan kekerasan ekonomi 13 persen sebagaimana tergambar dalam tabel 2 di bawah ini.

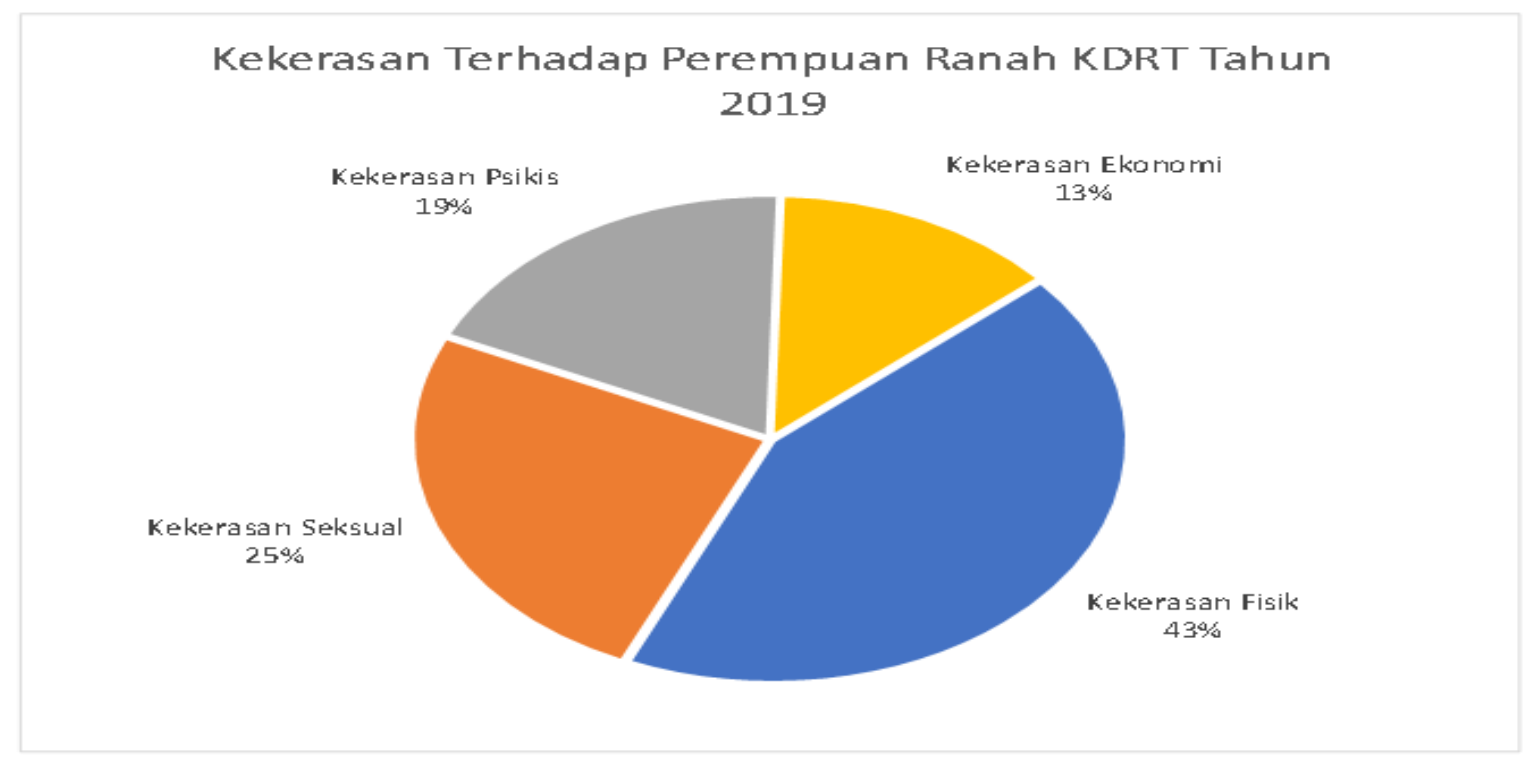

Tabel 2. Komnas Perempuan, Catatan Tahunan Tentang Kekerasan Terhadap Perempuan Tahun 2020(Komnas Perempuan, n.d.-a)

Data-data di atas sudah membuktikan bahwa wujud kekerasan yang paling menonjol adalah KDRT. Dan hal ini pula merupakan persoalan yang sering menjadi keluhan dari para rohaniawan sebagaimana yang diobservasi oleh tim peneliti.

Kalangan wanita di ranah publik juga memiliki prosentasi tingkat kekerasan yang besar dengan 3.602 kasus (atau 24\%) sedangkan kekerasan terhadap perempuan di ranah negara dengan persentase $0.1 \%$ (atau 12 kasus).

Informasi Komnas Perempuan tentang KDRT terkait ranah Personal menunjukkan bahwa kekerasan yang paling menonjol adalah kekerasan fisik 4.783 kasus (atau $41 \%$ ), disusul kekerasan seksual sebanyak 2.807 kasus (atau $25 \%$ ), kekerasan psikis 2.056 (atau $19 \%$ ) dan kekerasan ekonomi 1.459 kasus (atau13\%) dari jumlah kasus-ksus kekerasan yang terjadi selama ini.

Dalam memo Akhir Tahun dari Rumah Perempuan terkait tahun 2015 yang lalu, menjelaskan tingkat kekerasan kepada kaum wanita pada Kabupaten Kupang dan Kota Kupang menunjukkan jumlah kasus yang tinggi. Selama kirun waktu 15 tahun Rumah Perempuan sudah mendampingi 1.144 kasus KDRT yang terjadi di Kota Kupang dan Kabupaten Kupang dan pada tahun 2015, ada 102 kasus KDRT atau $25 \%$ dari jumlah kasus kekerasan terhadap wanita dan anak yang didampingi. Jumlah kekerasan terhadap perempuan tersebut hanyalah merupakan potret kasus-kasus yang terungkap dan telah ditangan, juga tentu saja belum tercantum wujud kekerasan yang tidak turut dilaporkan oleh kaum wanita sebab rasa malu, takut dan aspek budaya lainnya.

Wujud KDRT diantaranya kekerasan fisik selaku perbuatan yang menyebabkan rasa sakit, jatuh sakit, atau cidera berat; Kekerasan psikis, adalah perbuatan yang memicu ketakutan, hilangnya rasa percaya diri, hilangnya kemampuan untuk bertindak, rasa tidak berdaya, dan atau penderitaan psikis berat; Kekerasan seksual, adalah pemaksaan hubungan seks baik kepada anggota keluarga dalam rumah atau sekitar, termasuk untuk tujuan komersial atau tujuan tertentu; Pengabaian adalah tindakan mengabaikan orang yang sebetulnya menurut hukum menjadi tanggungjawabnya. 
Poerwandari(Poerwandari, n.d., p. 11) merumuskan wujud KDRT atas lima bagian yakni a) kekerasan fisik, b) kekerasan psikologis, c) kekerasan seksual, d) kekerasan finansial dan e) kekerasan spiritual. Akan diselediki apakah kelima wujud kekerasan ini juga ada terjadi pada para pendeta Korban KDRT atau hanya sebagian saja. Tentu ini pula hal ini adalah sesuatu yang patut didalami.

Dalam UU No. 31 tahun 2014 mengenai Proteksi Saksi serta Korban khususnya ketentuan Pasal 5, Pasal 6 dan Pasal 7 memberi perhatian pada aspek korban tindak pidana kekerasan dalam rumah tangga, dimana mereka berhak memperoleh perlindungan.(LEMBARAN NEGARA REPUBLIK INDONESIA, n.d.)

Hal ini menampilkan data bahwa KDRT adalah fenomena yang merongrong kehidupan manusia khususnya wanita. Tak terkecuali para wanita yang berprofesi sebagai pendeta. Bersumber pada data personil MS GMIT bahwa sampai dengan Desember 2019 sudah ada 10 kasus KDRT yang terkait dengan kekerasan fisik, psikis dan penelantaran. Fakta ini memberi gambaran GMIT sudah mencoba mendampingi para pendeta perempuan untuk keluar dari permasalahan KDRT yang ada. Namun pertanyaannya apakah masalah KDRT yang dialami oleh para pendeta korban KDRT sudah tertasi dan terpecahkan persoalannya dari pendampingan yang mereka peroleh dari lembaga gereja?

Di dalam KBBI(Hasil Pencarian - KBBI Daring, n.d.) istilah pendampingan bisa dbuat secara perorangan atau lembaga, dimana antara kedua belah pihak (pendamping dan yang didampingi) terdapat kesetaraan, kemitraan, kerjasama, kebersamaan tanpa ada batas golongan (kelas atau status sosial) yang tajam”.

Pendampingan merupakan pertemuan empat mata antara pendamping dan korban untuk mempercakapkan masalah-masalah yang dihadapinya. Wiryasaputra menggunakan istilah pendampingan selaku proses perjumpaan pendamping dan korban, yang sifat dan maksudnya untuk menolong korban. Pada proses itu adanya interaksi yang bermuara kepada gagasan maupun jalan keluar ketika menghadapi masalah"(T. S. Wiryasaputra, 2006, p. 57) Jadi bisa disimpulkan bahwa kegiatan pendampingan merupakan suatu proses kerjasama yang melibatkan kedua bela pihak dalam hal ini para pendamping (pelayan gereja atau tim ahli dan para pendeta perempuan korban KDRT) yang tujuannya untuk menolong, mendampingi korban keluar dari permasalahannya. Disini diperlukan juga bahwa para pendamping bisa memperlihatkan kepedulian, simpati dan keberpihakan kepada korban. Jika ini tidak mampu ditunjukkan oleh para pendamping, maka para korban akan menutup diri dan membatasi interaksi mereka dengan para pendamping. Dan tentu saja pada gilirannya akan membatasi langkah-langkah penyembuhan bagi para pendeta korban KDRT.

Perhatian serta keberpihakan pada korban semestinya diteruskan dengan pendampingan korban yang sifatnya mendalam dan berkelanjutan. Pada penelitiannya pada para korban kekerasan di kamp-kamp Nazi, Viktor Frankl mendapati bahwa salah satu kebutuhan dasar manusia adalah kebutuhan akan makna. Saat menemukan makna dalam situasi penderitaan hidupnya, maka seseorang akan merasa terbebas dan bahagia. Penemuan makna itu menurut Frankl akan mengarahkan seseorang kepada suatu orientasi yang lebih baik ke masa depan yang lebih optimis, dan bukan lagi kembali ke belakang kepada trauma dan kenangan buruknya. Ia akan mengarahkan dirinya kepada pertanyaan-pertanyaan yang lebih bermakna, misalnya "apakah sebenarnya makna kehidupan yang dituntut dari dirinya?" setelah mengalami peristiwa-peristiwa pahit dalam dirinya.

Dengan cara itu, seseorang mampu mengalihkan persoalan penderitaan kepada penemuan makna. Dan peralihan ini menjadikan seseorang menjadi penyintas atau orang yang telah mampu melewati pengalaman kekerasan dan bangkit untuk menatap kehidupan di depannya dengan lebih baik. Berdasarkan kepada teori Frankl ini, maka masalah pendeta korban KDRT hendaknya ditanggapi melalui tindakan yang menyeluruh, baik dalam tahap pencegahan, tahap pendampingan, hingga tahap pasca kekerasan dengan menjadikan 
pendeta korban KDRT sebagai subjek yang juga berjuang untuk mengeleminir atau setidaknya meminimalisir persoalan KDRT yang dihadapinya.

Perlu dijelaskan disini hal-hal apa saja yang menjadi peran dari para pendamping. (Lutfia, 2016, pp. 17-18) merumuskan paling kurang ada empat peran penting yang harus dimainkan oleh para pendamping di antaranya: pertama, seorang pendamping berperan sebagai seorang advocator (pembela). Pendamping melakukan pembelaan kepada korban KDRT yang mendapatkan perlakuan tidak adil; kedua, pendamping berperan sebagai midiator (penengah atau penghubung). Pendamping berperan sebagai penghubung korban KDRT dengan sistem sumber yang ada baik formal maupun informal; ketiga, pendambing berperan sebagai enaber (pemungkin). Pendamping berperan memberikan kemudahan kepada korban KDRT untuk memahami masalah, kebutuhan, potensi yang dimilikinya, dan mengembangkan upaya penyelesaian masalah; dan yang keempat pendamping berperan sebagai motivator (pemberi motivasi. Pendaping berperan memberikan rangsangan dan dorongan semangat kepada penerima manfaat untuk bersikap positif, sehingga dapat mengembangkan potensi yang dimilikinya.

Para pendamping mesti menyadari bahwa upaya menolong para pendeta korban KDRT bukanlah perkara mudah seperti orang membalikan telapak tangan, melainkan harus melalui berbagai tahapan penting. Kita tidak dapat mengatakan bahwa cukup dengan melakukan penyuluhan sebagai upaya pencegahan berupa penyadaran kepada anggota masyarkat dan anggota gereja tentang KDRT, maka semua masalah KDRT akan selesai. Atau mengumpulkan para pendeta perempuan yang mengadali KDRT dalam suatu ruangan dan mengajak mereka menyanyikan lagu kristen dan diakhir dengan doa, maka persoalan mereka juga berakhirn. Tentu saja hal ini tidak bisa terjadi bergitu saja, sebab kendatipun semua bentuk penyadaran berupa penyuluhan, mengajak bernyanyi dan berdoa yang dilakukan berbagai pihak, tetapi ternyata persoalan kekerasan tetap saja terjadi. Disinilah pentingnya para pendamping untuk mendampingi para korban KDRT secara lebih intens dan berkelanjutan dalam berbagai tahap yang harus dilewati.

Pada tempat pertama adalah tahap pendampingan yang merupakan proses pendampingan saat korban mengalami KDRT. Para pendeta Korban KDRT tidak boleh dibiarkan sendiri menghadapi masalahnya yang sedang dihadapinya. Dan pada tempat yang kedua yaitu tahap pasca kekerasan, merupakan tahap dimana para pendamping menemani korban setelah masa-masa KDRT. Tujuan dari tahap pasca kekerasan ini adalah untuk membantu korban menemukan makna hidupnya melalui pengalaman KDRT yang dialami. Sehingga melalui pengalaman yang dialami dan penemuan makna yang dari para korban tentunya akan membantu para korban lain atau komunitas di sekitarnya untuk mencegah dan menghentikan KDRT. Sehingga korban tidak lagi menjadi korban tetapi menjadi penolong dan inspirator penyembuhan bagi para pendeta korban KDRT lainnya.

\section{Upaya GMIT}

Secara teoritis Gereja Masehi Injili di Timor (GMIT) telah memiliki dokumendokumen gereja yang bisa diandalkan dalam upaya menolong para pendeta korban KDRT. Sebab hal ini sudah tergambar dalam misi GMIT itu sendiri. Sebagai gereja yang ditempatkan Allah di dalam dunia ini tugasnya untuk menyatakan misi dan panggilannya, yaitu mewujudkan misi Allah dalam mewujudkan tanda-tanda Kerajaan Allah, dan hal itu tidak hanya di Sorga tetapi juga di Bumi ini, di kota Kupang, di NTT, di Indonesia. Demi mewujutkan Kerajaan Allah, sudah seharusnyalah seluruh daya dalam gereja baik ajaran maupun program terarah pada pemenuhan misi Allah. Dengan demikian hakikat gereja (Being) terlihat jelas dalam pelayanan gereja (Doing). Hakekat dan keberadaan Gereja sebagai perpanjangan tangan Allah di dalamm dunia dapat berwujud dalam pelayanan dan karya-karya yang nyata di tengah-tengah konteks yang penuh dengan kasus-kasus KDRT 
teruatama bagi para pendeta korban KDRT. Disini keterpanggilan GMIT mesti nampak kepada pemberian ruang yang baik bagi penetapan ajarannya, programnya dan prosedurprosedur tetap dan program-program gereja yang memadai dalam penanganan terhadap para pendeta korban KDRT.

Keterpanggilan dan kesadaran untuk memperhatikan dengan serius masalah pendeta korban KDRT telah terlihat dalam Dokumen Resmi Gereja yakni Naskah "Pokok-pokok Eklesiologi GMIT" tentang keluarga kristen. Keluarga merupakan inti dan basis dari pelayanan gereja telah menjadi bagian dari percakapan GMIT dan bahkan telah diputuskan dalam dokumen-dokumen hasil persidangan gereja. Keluarga kristen sebagai keluarga yang di dalamnya nilai-nilai kekristenan dibangun dan dikembangkan merupakan titik tolak pelayanan yang tidak luput dari banyak masalah. Salah satu masalah hebat yang sedang dihadapi oleh keluarga kristen di GMIT adalah kekerasan dalam rumah tangga (Sinode, 2010, p. 14). Kesadaran akan konteks KDRT yang telah tergambarkan naskah eklesiologis ini, hendaknya juga diamanatkan pada ajaran dan program nyata gereja dari lingkup jemaat, klasis, dan sinodal.

\section{METODE PENELITIAN}

Penelitian deskriptif kualitatif adalah pilihan utama dari metode penelitian ini. Penelitian deskriptif kualitatif menurut (Moleong, 2012), adalah penelitian yang bermaksud memahami fenomena tentang apa yang yang dialami oleh subyek penelitian, misalnya perilaku, persepsi, motivasi, tindakan dan lain-lain secara holistik dan dengan cara deskripsi dalam bentuk kata-kata dan bahasa pada suatu konteks khusus yang alamiah dan dengan memanfaatkan metode alamiah. Manfaat dari Penelitian kualitatif terutama untuk memahami isu-isu yang sensitif, untuk memahami fenomena yang sampai sekarang belum banyak diketahui dan juga untuk menelaah suatu latar belakang, misalnya tentang motivasi, peranan, nilai, sikap dan persepsi.

Di sini akan digunakan metode wawancara dan penelaahan dokumen. Wawancara dilakukan dengan para Pendeta korban KDRT dengan menggunakan dua tipe wawancara. Teknik wawancara seperti yang dikatakan oleh Strains dan Corbin terdiri dari wawancara mendalam dan wawancara terbuka. Wawancara mendalam adalah wawancara dengan pertanyaan terstruktur dan melakuan pengembangan pertanyaan sesuai dinamika jawaban dari informan. Hasil yang ingin didapatkan melalui wawancara mendalam ini adalah untuk mendapatkan pemahaman yang mendalam tentang suatu masalah. Sedangkan wawancara terbuka berarti melakukan percakapan informal yang bertujuan menggali pemahaman melampaui observasi dengan berbasis pemeriksaan latar belakang masalah, menemukan gagasan baru, memeriksa keabsahan dan keandalan. Dirasa perlu juga menggunakan alat bantu berupa voice digital record dan media lainnya yang mendukung.

\section{Subyek Penelitian}

Para pendeta korban KDRT di lingkup pelayanan GMIT merupakan sasaran dari penelitian ini. Metode pengambilan sampel responden dilakukan secara purposive sampling, contohnya seperti yang telah dilakukan oleh (Widartha, 2006), yaitu teknik pengambilan sampel yang ditetapkan secara sengaja berdasarkan kriteria atau pertimbangan tertentu, karena itu responden dalam penelitian ini adalah pendeta korban KDRT. Lokasi penelitian adalah para pendeta yang berada di Kota Kupang, Nusa Tenggara Timur, Indonesia

\section{Teknik Pengumpulan Data}

Interview adalah bagian dari percakapan yang terfokus pada tujuan penelitian. Tujuan dari wawancara adalah memastikan realibilitas dan validilitas data dalam penelitian kualitatif. Artinya sedapat mungkin menemukan informasi yang dipercaya atau kredibel, 
ketimbang merefleksikan informasi yang bias dan hanya mewacanakan perspektif satu kelompok. Secara umum dalam penelitian interview mencakup beberapa macam. Pertama interview semi struktur artinya dapat bimbing oleh tema dan topik yang ada dan dipercakapkan bersama. Kedua, Indeepth interview artinya wawancara pendalaman bertujuan mengali atau mengeksplorasi lebih detail perspektif atau fakta yang ada.

Observasi merupakan sebuah proses pengamatan yang dilakukan untuk memahami fenemona atau komplexsitas situasi. Terutama berhubungan dengan faktor dan kejadian keseharian. Efektivitas proses observasi ditentukan rencana, fokus dan waktu yang dibutuhkan.

Dalam penelitian atau studi terfokus partisipasi merupakan kunci sejauhmana interaksi peneliti wilayah penelitian atau responden. Unsur ini penting sebab seorang peneliti mesti berupaya menjadi subyek, dalam pengertian menempatkan diri sebagaimana narasumber agar dapat memahami situasi para pendeta korban KDRT dengan baik. Partisipasi atau keterlibatan tersebut boleh dilakukan dengan mengikuti kegiatan keseharian mereka atau mencari moment-moment tertentu sebagai acuan.

Malalui partisipasi peneliti dapat mengetahui lebih dalam situasi yang ada sekaligus menemukan gambaran yang lebih lengkap mengenai sebuah konteks. Partisipasi juga dapat menolong peneliti untuk menemukan hal-hal kunci yang sulit ditemukan atau hidding data. Berhubungan dengan penelitian ini penulis akan fokus pada partisipasi sebagai proses keterlibatan bersama dengan para narasumber terutama untuk mengetahui faktor terjadinya KDRT di kalangan pendeta.

Metode dokumenter adalah pengumpulan data melalui berkas mengenai hal-hal yang berupa catatan, agenda, transkrip, notulen, tentang pendapat, teori dan lain sebagainya yang berhubungan dengan masalah yang di teliti. Maka jelas bahwa data dokumenter akan diarahkan pada dokumen-dokumen pelayanan para pendeta korban KDRT.

\section{HASIL PENELITIAN DAN PEMBAHASAN}

Dari hasil penelitian terbukti bahwa faktor-faktor penyebab pendeta perempuan mengalami kekerasan dalam rumah tangga (KDRT) masalah gangguan psikologis dari pasangan, masalah gangguan seksual, faktor minuman keras, kesibukan korban dalam pelayanan.

KDRT yang disebabkan oleh masalah gangguan jiwa nampak dalam salah seorang pendeta perempuan korban KDRT dan itu sudah dialami sejak tahun 2002. Sehari-hari suaminya nampak baik, tetapi dengan tiba-tiba dan tanpa sebab meninju istrinya yang merupakan pendeta jemaat, jika ia sedang duduk dan bercakap-cakap dengan anggota jemaat laki-laki yang datang ke rumah pendeta. Kekerasan dapat berupa makian kata-kata kotor, pukulan dan tendangan, dimana korban sempat dibawah ke rumah sakit karena babak belur.

KDRT yang diakibatkan oleh masalah ganggunan seksual terjadi karena korban menolak untuk berhubungan seks yang diminta oleh pelaku setiap hari. Bahkan dalam sehari bisa 3 sampai 5 kali hingga lebih. Sebagai pendeta perempuan yang harus melayani jemaat sebagai pendeta, juga harus berbagi waktu dengan keluarga, maka sulit baginya untuk melayani suami yang hypperseks tersebut, akibatnya makian dan pukulan yang ia terima hampir setiap harinya.

KDRT yang dipicu oleh minuman keras dari pasangan korban pendeta perempuan terjadi memang tidak setiap hari, tetapi ketika dia mengalaminya, maka ia sangat sakit dan menderita. Suami yang sejak muda hobby miras, terbawa dalam pernikahan, dan ketika pasangannya mabuk, maka sang pendeta perempuan dan anak-anak menjadi korban kekerasan di dalam rumah tangga.

KDRT yang disebabkan oleh kesibukan istri dalam pelayanan juga dapat menjadi pemicu kekerasan. Sang suami tidak dapat menerima jika sang pendeta perempuan harus 
menghabiskan waktu berjam-jam di gereja dan seakan-akan melupakan dia dan anakanaknya. Ada nada kecemburuan bahwa sang pendeta perempuan lebih mementingkan pelayanan dari pada keluarganya. Akibatnya kata-kata makian dan pukulan sering di dapat oleh sang pendeta perempuan.

Faktor lain yang memicu KDRT adalah faktor kecemburuang pasangannya. Suami dari korban menuduh istrinya yang nota bene seorang pendeta melakukan perselingkuhan. Dan ini yang memicu KDRT dalam rumah tangga, makian dan pukulan tangan tidak dapat dihindari lagi dimana terjadi hampir setiap hari.

Pada salah salah satu pendeta Korban KDRT, faktor penyebabnya juga karena pasangannnya tidak memiliki pekerjaan tetap, sehingga seringkali terjadi pertengkaran dalam rumah tanga. Hal ini makin diperparah karena tingkat pendidikan suami tidak seimbang dengan korban yang bergelar sarjana, sementara pelaku hanya tamatan SMA.

Penelitian juga melihat terjadinya kekerasan terhadap pendeta perempuan disebabkan oleh berbagai faktor. Diantaranya masalah budaya, masalah ekonomi, masalah memahami teks alkitab secara salah, bahwa laki-laki adalah kepala keluarga, maka perempuan tidak boleh melawan baik melalui tutur kata, bahasa tubuh maupun tindakan yang dapat dianggap sebagai melecehkan kaum lelaki sebagai kepala keluarga.

Sementara itu peranan Institusi Gereja dan Badan-badan pelayanan Gereja belum sepenuhnya menjadi sahabat dan pendamping bagi para Pendeta korban KDRT. Hal itu tergambar dari kesaksian hampir semua responden. Berdasarkan perspektif mereka fungsi badan pastoral di lingkup sinode belum dijalankan secara optimal, karena para korban merasa pelayanan hanya terbatas saran-saran dan tidak ada waktu mendalami permasalahan para korban. Peran pendampingan sebagai seorang advocator dan mediator tidak nampak sama sekali sebagaimana yang diungkapkan dalam kajian teori di atas. Ketika para korban mengeluhkan tentang aturan gereja yang masih bersikap diskriminatif terhadap para pendeta korban KDRT, para pendamping tidak mampu memberikan jalan keluar, atau paling tidak menjadi penghubung antara korban dan pihak pemimpin gereja agar dicarikan solusinya. Begitu pula fungsi para pendamping sebagai motivator tidak dijalankan secara maksimal dan hanya sekedar memberikan saran dan nasehat yang tidak langsung menyentuh akar permasalahan, sehingga para korban merasa para pendamping kurang menunjukkan rasa simpati kepada persoalan KDRT yang sedang mereka hadapi.

Dalam khasus pendeta perempuan yang mengalami KDRT Institusi gereja, yang dalam hal ini diwakili oleh Unit pelayanan Pastoral, yang semestinya dapat menjadi sahabat dan pendamping yang baik bagi para pendeta korban KDRT, ternyata kurang menjalankan fungsi pastoral dan pendampingan mereka dengan baik. Padahal secara teologis mereka terpanggil justru pada saat-saat para pendeta korban KDRT bergelut dengan permasalahan mereka.

Yesus Kristus mengatakan bahwa barangsiapa yang menjadi murid dan pengikutnya yang setia, justru terpanggil untuk menjadi sahabat dan pendamping bagi orang-orang yang menderita. Karena dengan melayani mereka, maka hal itu sama dengan melayani Kristus sendiri (Matius 25:35-40). Jadi ketika gereja merawat dan mengobati para pendeta korban KDRT, sebetulnya gereja sedang merawat Kristus sendiri, karena menjadi sahabat bagi orang-orang yang menderita sebetulnya gereja menjadi sahabat sesungguhnya dari Kristus.

Dalam Matius 25:40 dan juga Matius 10:42 menurut (Nixon, R.R, Matthew, dalam Guthrie, 1970, p. 846) Yesus memberikan penegasan kepada para muridnya bahwa apapun tindakan kecil yang diberikan kepada orang kecil yang membutuhkan pertolongan sebentulnya hal itu dilakukan untuk Kristus sendiri dan itu ada upahnya. "Aku berkata kepadamu, sesungguhnya segala sesuatu yang kamu lakukan untuk salah seorang dari saudara-Ku yang paling hina ini, kamu telah melakukannya untuk Aku" (Matius 25:40). "Dan barangsiapa memberi air sejuk secangkir sajapun kepada salah seorang yang kecil ini, 
karena ia murid-Ku, Aku berkata kepadamu: Sesungguhnya ia tidak akan kehilangan upahnya dari padanya." (Matius 10:42). Dari gambaran teks Injil Matius di atas menunjukkan bahwa gereja sebagai sebuah lembaga mestinya memainkan peranannya secara maksimal untuk mendapingi para pendeta korban KDRT untuk keluar dari permasalahan mereka.

Gereja sebagai sebuah persekutuan mesti memainkan peranannya sebagai gereja yang menyembuhkan yang mampu menyalurkan cinta kasih Allah kepada sesama yang sedang dalam kesulitan. Dan ketika gereja menunjukkan kasih Allah kepada para pendeta korban KDRT disitulah gereja mewujudkan dirinya sebagai gereja sejati, yang tidak saja berwacana tentang kasih, tetapi mewujudkan kasih melalui proses pendampingan yang baik kepada para pendeta korban KDRT. Karena menurut penulis kitab 1 Yohanes "kita mengasihi bukan dengan perkataan atau dengan lidah, tetapi dengan perbuatan dan dalam kebenaran" (1 Yoh.3:18).

Pendampingan yang baik dan berkualitas adalah buah-buah iman yang nyata. Kita tidak berbuat baik untuk mendapatkan keselamatan, namun karena kita sudah selamat, maka kita menghasilkan buah-buah keselamatan itu. Pendampingan yang berkualitas kepada para pendeta Korban KDRT adalah buah atau bukti keselamatan karena kita telah mendapatkan kasuih Karunia Allah (Efesus 2:8-10). Maknanya ialah bahwa komitmen kepada Kristus mendorong gereja menghasilkan pelayanan dan pendampingan yang berkualitas kepada para pendeta korban KDRT. Gereja terpanggil dan ditempatkan dalam dunia untuk mewujudkan kebaikan dan kepedulian Allah kepada orang-orang yang bermasalah seperti para pendeta korban KDRT.

Jika hal ini tidak dilakukan maka sebetulnya gereja memang ada tetapi ia telah mati, seumpama manusia yang memiliki tubuh, tetapi tanpa roh dan jiwa lagi. Gereja mungkin masih ada sebagai sebuah lembaga, tetapi tidak lagi berjalan dalam tuntunan Roh Allah. Kitab Yakobus menekankan penting tuntunan Roh untuk mewujudkan perbuatan-perbuatan baik kepada para pendeta korban KDRT. "Sebab seperti tubuh tanpa roh adalah mati, demikian jugalah iman tanpa perbuatan-perbuatan adalah mati" (Yak. 2:26). Artinya sebagai pengikut Kristus gereja mewujudkan dirinya sebagai pelaku-pelaku Firman Allah. "Tetapi hendaklah kamu menjadi pelaku firman dan bukan hanya pendengar saja; sebab jika tidak demikian kamu menipu diri sendiri. Sebab jika seorang hanya mendengar firman saja dan tidak melakukannya, ia adalah seumpama seorang yang sedang mengamat-amati mukanya yang sebenarnya di depan cermin. Baru saja ia memandang dirinya, ia sudah pergi atau ia segera lupa bagaimana rupanya. Tetapi barangsiapa meneliti hukum yang sempurna, yaitu hukum yang memerdekakan orang, dan ia bertekun di dalamnya, jadi bukan hanya mendengar untuk melupakannya, tetapi sungguh-sungguh melakukannya, ia akan berbahagia oleh perbuatannya (Yak.1:22-25).

Gereja harus mampu mewujudkan dirinya sebagai bagian dari Kristus dan sungguhsungguh mengenal Kristus. Kristus memiliki kepedulian kepada orang-orang yang bermasalah dan berbeban berat. Jadi jika gereja berwacana tentang kebaikan dan mengaku mengenal Kristus, maka pada saat yang sama ia juga harus mampu memberikan layanan terbaik kepada para pendeta korban KDRT. Sebab "barangsiapa berkata: Aku mengenal Dia, tetapi ia tidak menuruti perintah-Nya, ia adalah seorang pendusta dan di dalamnya tidak ada kebenaran. Tetapi barangsiapa menuruti firman-Nya, di dalam orang itu sungguh sudah sempurna kasih Allah; dengan itulah kita ketahui, bahwa kita ada di dalam Dia. Barangsiapa mengatakan, bahwa ia ada di dalam Dia, ia wajib hidup sama seperti Kristus telah hidup" (1 Yoh 2:4-6). Dan Kristus sendiri mengatakan: "Jikalau kamu mengasihi Aku, kamu akan menuruti segala perintah-Ku. Teks-teks Alkitab di atas semakin memperkuat agar gereja sungguh-sungguh peduli kepada pendampingan yang baik dan berkualitas bagi para pendeta 
korban KDRT. Yesus memerintah agar supaya gereja sebagai sebuah persekutuan orang percaya untuk saling mengasihi satu dengan yang lain (Yohanes 13:34-35).

\section{SIMPULAN}

Apakah tindakan MSH GMIT dalam hal ini UPP Pastoral menyikapi fenomena para pendetanya mengalami KDRT dari pasangan mereka? MSH GMIT melalui UPP Pastoral oleh para pendeta perempuan korban KDRT dinilai belum melakukan proses pendampingan yang efektif. Hal ini terjadi karena beberapa alasan.

Pertama karena peran pastoral secara kelembagaan belum dijalankan secara optimal. Para korban merasa bahwa layanan yang diberikan masih sebatas pemberian saran-saran tanpa melakukan pendalaman terhadap persoalan yang dialami oleh para korban. Untuk itu fungsi badan pastoral di semua lingkup perlu dioptimalkan secara terencana sebagai bentuk dukungan psikososial untuk mencegah dan memutus mata rantai kekerasan dalam rumah tangga.

Kedua, belum adanya protap atau SOP yang memungkinkan proses pemulihan bagi para korban itu dilakukan secara terencana dan sistimatis sebagai bagian dari support system lembaga kepada korban baik di lingkup jemaat, klasis dan sinode. Langkah ini diperlukan untuk menutup kemungkinan terburuk terjadinya dampak-dampak lain dari proses penantian yang panjang untuk sebuah pemulihan status bagi para pendeta korban KDRT.

Ketiga, proses penarikan pendeta perempuan korban KDRT dari pelayanannya dijemaat menimbulkan stress dan depresi baru bagi para korban. Lembaga perlu melihat bahwa tidak semua korban harus ditarik penempatannya dari jemaat dengan alasan untuk menjalani masa pastoral. Sebab korban selama menjalani masa pastoral dapat memposisikan korban dalam keadaan yang semakin terpuruk karena harus kehilangan penghasilan akibat proses penarikannya dari jemaat. Para korban merasa ruang advokasi dan mediasi belum benar-benar terbuka bagi mereka. Dalam proses hukum terkait kekerasan yang dialami termasuk didalamnya dibutuhkan advokasi bagi korban, khsususnya ketika korban memilih untuk bercerai sebagai pemenuhan hak sipilnya. Para korban merasakan situasi seperti orang yang sudah jatuh tertimpa tangga pula, akibat dari stigma-stigma negatif baik dari rekanrekan pendeta maupun jemaat. Stigma negatif terhadap pendeta korban KDRT yang masih dirasakan oleh korban dalam relasi sosialnya khususnya dengan rekan-rekan korban sebagai pendeta. Karena itu perlu ada ketegasan dari lembaga agar korban KDRT tidak mengalami kekerasan ganda dalam menghadapi KDRT.

Oleh karena itu, hal yang patut direkomendasikan kepada lembaga Sinode GMIT adalah perlunya optimalisasis lembaga pelayanan pastoral yang dimiliki GMIT. Juga perlu disusunnya Protap atau SOP langkah-langkah pemulihan pendeta korban KDRT. Dan terakhir perlunya ruang dampingan dan advokasi pastoral berkelanjutan agar para korban benar-benar pulih dari trauma yang dialami.

\section{DAFTAR PUSTAKA}

Agustin, K. (2017). Komitmen Struktural: Dinamika Psikologis Pada Istri Korban KDRT (Kekerasan Dalam Rumah Tangga) Yang Tetap Mempertahankan Perkawinan. Skripsi Program Studi Psikologi, Fakultas Ilmu Sosial dan Humaniora, Universitas Islam Negeri Sunan Kalijaga Yogyakarta.

Dethan, Mesakh Abia Pello. (2013). Church Efforts on Strengthening Women Capacity to Fight Household Violence In Kupang. International Research Journal of Management, IT \& Social Science. https://sloap.org/journals/index.php/irjmis/ terutama lihat DOI: https://doi.org/10.21744/irjmis.v6n5.744 
Hardiman, F. Budi. (2011) Massa, Teror, dan Trauma. Maumere: Lamalera.

Ishkandar (2009). Metode penelitian kualitatif. Persada.

Ketut, S. D. (2002). Pengantar Pelaksanaan Progrm Bimbingan dan Konseling di sekolah. Rineka Cipta.

KBBI (2008), Pusat Bahasa Departemen Pendidikan Nasional. Pusat Bahasa.

Poerwandari, K. (2002). Kekerasan terhadap perempuan. Tinjauan Psikologis Feminis, dalam Pemahaman Bentuk-bentuk Kekerasan Terhadap perempuan dan alternatif pemecahannya. Universitas Indonesia.

Lutfia, A. (2016). Pemberdayaan Perempuan Korban KDRT Dalam Pelaksanaan Pendampingan Berbasis Perspektif Gender di LSM Annisa Yogyakarta. Skripsi Program Studi Pendidikan Luar Sekolah, Fakultas Ilmu Pendidikan, Universitas Negeri Yogyakarta.

Merlinda, F. (2016). Pendampingan Psikososial Terhadap Perempuan Korban Kekerasan Dalam Rumah Tangga di Balai Perlindungan dan Rehabilitasi Sosial Wanita (BPRSW) Yogyakarta. Skripsi Fakultas Dakwah dan Komunikasi, Universitas Islam Negeri Sunan Kalijaga Yogyakarta.

Majelis Sinode. (2010). Naskah Eklesiologi GMIT: Tata Gereja GMIT Tahun 2010. Majelis Sinode GMIT.

Miles, M, B. \& Huberman, Michael. (1992). Analisis Data Kualitatif, Dterjemahkan oleh Tjetjep Rohendi Rohidi. Universitas Indonesia Press.

Marliana, T. (2012). Kajian Tentang Pengalaman Hidup Perempuan Korban Trafficking dalam Perspektif Kesehatan Jiwa. Tesis Program Magister Ilmu Keperawatan Jiwa, Universitas Indonesia.

M.D., Judith, H. (1997). Trauma and Recovery. Basic Books.

Moleong, L. (2012). Metode Penelitian Sosial dan Pendidikan. PT Remaja Karya Rosdakarya.

Nixon, R.R, Matthew, dalam Guthrie, D (Ed.). (1970). New Bible Commentary, Third Edition. Inter-Varsity Press.

Purwanto, L., H. (2010). Pendekatan Teologi untuk Menyusun Tata Gereja. UKAW Kupang Rumah Perempuan Kupang (2015). Catatan Akhir Tahun 2015. Rumah Perempuan Kupang. Wirartha, I., Made. (2008). Pedoman Penulisan Usulan Penelitian Skripsi dan Tesis. Jakarta, Andi.

Wiryasaputra, T. S. (2006). Pendampingan dan Konseling Psikologi. Galang Press.

Zuriah, N. (2007). Metode Penelitian Sosial dan Pendidikan. Bumi Aksara. 